\title{
Citizen Participation in the Network Age in East
}

\section{Asia}

MIN LI

School of Gender and Social Development,

China Women's University,

Beijing, China

\section{About the author}

Min Li is currently an associate professor at China Women's University, China. She received her doctoral degree from Renmin University of China in 2009. During 2010-2012, she conducted postdoctoral research focusing on topics related to social work at Tsinghua University. She published thirty papers and two monographs, and led research of eight projects sponsored by the National Post-doctoral Science Fund. 


\section{Abstract}

With the rapid development of the Internet, globalization has entered a new phase. In the network age, the whole world share information resources on the same platform, which brought about more social changes as well as social problems. International comparison within the context of globalization provides a brand new perspective to solve these problems. This study investigates online citizen participation in Beijing, Seoul and Tokyo, and discovers the differences in terms of speech participation, organization participation and political participation among these three cities. The demographic analysis demonstrates a close connection among the situations in these three cities, including similarities in perceptions on social trust, social responsibility, confidence in sustainable economic development administrative framework as well as social structure. The research also concludes that the Internet has become a significant route of access to citizen participation for the Chinese.

Keywords: Network Age, Citizen Participation; Beijing, Seoul and Tokyo

\section{Introduction}

The purpose of this paper is to investigate the citizens' perceptions on economic development, social trust, social responsibility and citizen participation in Beijing, Seoul, and Tokyo. Citizen participation is an important part of public life. It is the cornerstone of democratic politics, as well as the source of social vitality. It gathers knowledge on various aspects from the masses, and provides timely and effective information for administrative staffs as to how to improve the creativity of governmental management (Wang and Ni, 2005).

With the worldwide mobility of human resources, the sharing of public power and citizen participation have exerted a significant influence on public affairs, and it has become a typical feature of the Confucius Cultural Circle (Tsutsui and Christine, 2004). In particular, with the development of IT, the network has become an open space for public opinions, where anonymous communication allows the individuals to express their genuine ideas and opinions with more freedom. Compared with traditional media, the Internet is more convenient and interactive in promoting citizen participation. Online communication has facilitated citizen participation, which has become the driving force for the progress in social politics and democracy. Therefore, more attention should be paid to issues related to citizen participation within the field of social work study. More detailed examination is needed to clarify the awareness and behavior of citizens as well as potential development in their social participation.

This paper focuses on citizen participation in Beijing, Seoul and Tokyo with the reciprocality of economy, institutional framework and culture taken into account. All these three cities belong to the so-called "Confucius Cultural Circle". In regard to economy, citizens' confidence in the future economic development of their own countries will be examined. Trust in government, stranger, media and non-profit organization will be taken into consideration as institutional factors. Cultural factors pertaining to social responsibility will be discussed. 


\section{Literature review}

\section{The Many Faces of Citizen Participation}

Citizen participation refers to all activities through which citizens attempt to exert influence on public policies and public affairs (Yu, 2006). Citizen participation provides opportunities for citizens to express their interests in social life, guarantees their right to improve their life quality, and maintains continuous communication and trust among citizens as well. Citizen participation sustains the legitimacy of the government policy on public affairs (Sun, 2005).

Many scholars tend to explore the citizen participation issue through the relationship between the government and the society. They suggest that a new behavior mode for citizen participation should be established to strengthen the administrative competence of the government, and enhance the management of the public, enterprises and non-profit organizations (Catherine, 2003). With the upgrade of cities and the improvement of social community structures, some researchers began to conduct research on diversified forms of citizen participation, and concluded that citizen participation is a powerful challenge to elite politics. They found that citizen participation is (1) a reproduction process for public policy formulation (Gordon, 1980); (2) likely to influence the efficiency of democratic process (Robert, 1994); and (3) an important form of administrative accountability (Wang, 2008; 2013). The metacriteria of citizen participation are competence and equality. The first definition mentioned above highlights the ability to pursue truth, authenticity, regulation, privilege and claims. It is the equivalent of the ability to obtain optimal decision under current social situation; the second and the third suggest that justice offers more opportunity for both individuals and political parties to fulfill their legal duties during the governance process (Thomas and Seth, 2000). These studies on citizen involvement cover topics such as citizen satisfaction, citizen participation and the enhancement of government competence driven by citizen activities.

The study of citizen participation in China dates back to the 1980s. At the basic theoretical level, there are some studies focusing on the implication of its concept, and its significant role in promoting social life and democracy. Some studies give descriptions on the historical development of citizen participation in China, and analyse the characteristics of the Chinese democratic system and the relationship between citizen participation and political stability (Shu, 2005). At the practical level, there are studies conducted by Chinese researchers to explore the problems regarding system building and implementation for citizen participation. Yu (2006) proposes that citizen participation should be regulated and overseen by law in order to guarantee orderly participation. Citizen participation is believed to be closely related to educational level, economic condition and social status of the citizens. Citizens with higher educational level and better economic condition are the main body of the participation in China while those in the lower social stratums have relatively weaker participation awareness (Zhou, 2005). Traditional citizen culture, lack of institutional support and limited participation ability are the three factors responsible for the inadequate development of citizens' participation in public affairs. The limited number of organizations supporting citizen participation 
prevents the establishment of an effective social system which guarantees active citizen participation. The plight has become a serious impediment to the spreading of citizen participation (Wu, 2008).

Internet offers a new platform for citizen participation. Based upon comparison of online citizen participation between China and western countries, some researchers notice the sharp rise in the number of citizens using the Internet in China and point out that Internet-based social participation provides a brand new communication channel between citizens and political leaders. Orderly citizen participation entails the creation of a just and efficient participation environment as guarantee (Fu, 2009). Some scholars compare the young citizens' awareness and their involvement in citizen participation in China, Japan and South Korea. They find out that the different development paths and the cultural backgrounds play a decisive role in the formation of the current situation for citizen participation in these three countries (Min, 2010). Practical studies regarding the influence of the popularisation of the Internet on citizen participation assume that the young generation in China are participating in political life under the following conditions: (1) through the Internet; (2) on a voluntary basis; (3) in association with other young people; (4) with mutual trust towards other people and society as the prerequisite; (5) for the purpose of sharing ideas and opinions. Under the influence of the Internet, social values and public spirits are spreading inherently and the participation awareness of young people in social life has been highly promoted (Liu, 2011). Therefore, some scholars study the social structure and the features of online citizen participation from the perspective of demographic sociology (Zhang and Zhou, 2010). They examine the relationship between personal desire for expression and social participation, and reach the conclusion that online comments and involvement should be treated as a form of social participation (Zhang, 2011¹).

\section{Types of Participation: Speech, Organization and Political Participation}

With the enhancement of social governance and the active citizen involvement in political affairs in China, citizen participation can be classified into the following four types in general: role-play type, subject-intervention type, resource-sharing type and activity-participation type (Duan and Zhang, 2008). Considering the relatively inactive citizen participation in Beijing, Seoul and Tokyo in comparison to other western countries, this paper will discuss and analyse this problem from the perspectives of speech participation, organization participation and political participation. The prerequisite of citizen participation is speech participation. Online speech participation refers to the involvement in communication and discussion via network platform. The feasibility and effectiveness of citizen participation are determined by whether the citizens have the freedom to voice their opinions in public, whether they have the intention to express themselves about public affairs, whether the society has built the channel for speech participation available to citizens, and whether the state power respects citizens' speech participation.

The Internet provides a platform for interpersonal communication, arouses enthusiasm of people in communication and satisfies the underlying communicative demands, which is impossible to realize through traditional devices. The Internet has gathered a huge population of netizens in the virtual world and stimulated intensive discussion due to its capacity to deal with large quantity of information simultaneously. In addition, the interactivity, interdimensional space-time, extensiveness and low cost for online communica- 
tion make citizen participation easier and more convenient. Online communities, such as blogs, forums and chat rooms, extend the width and depth of interpersonal contact, enrich the social network resources, and fulfil the citizens' psychological needs of being integrated into social community by serving the society and obtaining social recognition.

Organization participation refers to the involvement in all kinds of civilian activities. The nongovernmental organizations are an institutional carrier where citizens get organized on a voluntary basis. Since the late 20th century, non-governmental organizations have developed rapidly around the world with their activities permeating all aspects of social life. This has not only broadened the range of social citizen activities, but also brought about profound changes to citizen participation. At the current stage, non-governmental organizations occupy an important position in the diverse governance structures. The non-governmental organization is the main platform for citizens' orderly political participation in some countries. It cultivates citizens' concern for social affairs and strengthens their social responsibility (Wei, 2007). The development of non-governmental organizations offers a wider space for citizen participation, creates a good cultural environment for citizen participation and helps to improve the citizens' participation ability (Feng, 2008).

In modern politics, there are three theories which can be used to explain political participation. First, the theory of legitimacy, which emphasizes the importance of legal participation; second, the theory of decision-making, which persists that the goal of political participation is to influence the result of decisionmaking; third, the theory of concept-behavior, which advocates that understanding political knowledge is political participation $(\mathrm{Li}, 1995)$. In fact, there is barely any legal route for the majority of citizens to access "political participation" and have their opinions reflected in the formulation and implementation process for political decisions. That is why the theory of concept-behavior insists that any behavior or concept related to political affairs for whatever purpose should be considered as political participation, regardless of its vagueness. This paper defines political participation as "citizens' behavior to influence the political process via certain channels" (Li, 1995:64-65). The author believes that citizens' political participation is largely influenced by their economic situation, institutional structures and other social and psychological factors (Liu, 2005).

Online political participation refers to "the involvement in political procedures or social events through the Internet" (Zhu, 2010:17). It is "an action when individual citizens or citizen groups get involved in the government's decision-making process via the network to become familiar with the relevant information about policies, express their opinions and influence the result of political decision-making" (Zhang, 20112):20). It is also "a new method for public political participation, which is adopted by netizens through communication in virtual space" (Tang, 2009:1). This paper defines network political participation as citizens' procedural or non-procedural actions which aim to influence the political process.

With the globalization of economy and culture, multidimensional discourses have a significant impact on national decisions for countries in the Confucius Cultural Circle. The transnational companies and nonofficial organizations have stepped into East Asia and citizen participation through the Internet has become the driving force for social globalization. Therefore, the research questions of this paper are as follows: 
1. Is online citizen participation in China similar to or different from other selected countries in East Asia?

2. What are the influence of political, economic and cultural backgrounds on the similarities and differences in citizen participation among those countries?

\section{Methodology}

This paper analyses data from a social survey called "City Management and Citizen Awareness in Beijing, Seoul and Tokyo" (Table 1), which was conducted by Schools of Social Science at Tsinghua University (China), Seoul National University (South Korea) and Chuo University (Japan). Face-to-face interviews and online surveys were carried out in 2012 with citizens aged from 19 and above. The total valid sample size is 1,606, including 560 people from Beijing, 512 from Seoul and 534 from Tokyo. The survey on citizen awareness includes questions related to their mutual understanding and recognition about each other, public perception of social risks, awareness of sustainable development, social participation, social justice and trust.

The main variables in this study include socioeconomic variables, confidence in the economic development, social trust, social responsibility and citizen participation (Table 1). The socioeconomic variables are related to gender, education, marital status, household income, profession and social class. Social trust consists of public trust in government, stranger, media and non-profit organizations. Confidence in the economic development is evaluated by survey items such as "please indicate whether you agree to the statement that your country can keep sustainable economic prosperity in the future". Social responsibility is measured through a request to the survey participants to comment on special events or social issues.

Citizen participation consists of speech participation, organization participation and political participation. Speech participation refers to the participation in online discussion. Organization participation stands for the participation in social activities organized by NGOs. Political participation refers to the participation in citizen projects and the engagement in policy formulation. The participation in citizen projects is assessed through questions related to the participants' willingness and voluntariness to offer help to disaster victims. The engagement in policy formulation is measured by comments of the participants on (1) policy-making related to effective urban development and (2) discrepancy between the opinions of the government and the netizens about social affairs in the policy-making process.

\section{Results}

Table 2 reports the result of speech participation, organization participation and political participation from a whole. When there is a dispute over political and social issues on the Internet, $25.5 \%$ of respondents from Beijing, $53.1 \%$ from Seoul and $4.5 \%$ from Tokyo indicate that they would get involved. Seoul has the highest proportion and Tokyo has the lowest. A large number of citizens from these three cities confirm that they have never participated in any social activity like NGOs. The participation rates for non-governmental social activities are 16.2\% from Beijing, 25.8\% from Seoul and 13.7\% from Tokyo respectively. When Fukushima in 
Table 1 Measures of variables

\begin{tabular}{|c|c|c|}
\hline \multicolumn{2}{|c|}{ variables } & explanations \\
\hline \multicolumn{2}{|c|}{ Socioeconomic variables } & Gender, education, occupation, marital status, household income, class \\
\hline \multirow{9}{*}{$\begin{array}{l}\text { citizen } \\
\text { participation }\end{array}$} & speech & $\begin{array}{l}\text { When there is a dispute over the state political and economic issues on } \\
\text { the Internet, have you ever participated in online discussions? }\end{array}$ \\
\hline & & (1) participation (2) non-participation. \\
\hline & organization & Have you ever participated in social activities organized by NGOs? \\
\hline & \multirow{6}{*}{$\begin{array}{l}\text { political } \\
\text { participation }\end{array}$} & $\begin{array}{l}\text { Have you ever got involved in the project launched to help the Japanese } \\
\text { victims in Fukushima Earthquake? If you have a chance, would you like } \\
\text { to make a contribution? }\end{array}$ \\
\hline & & $\begin{array}{l}\text { (1) participation (2) non-participation but with the intention } \\
\text { (3) no intention }\end{array}$ \\
\hline & & $\begin{array}{l}\text { Please mark your comment on the policy supporting effective urban de- } \\
\text { velopment. Do you agree that government should encourage citizens to } \\
\text { participate in policy-making? }\end{array}$ \\
\hline & & $\begin{array}{l}\text { (1) I completely agree. (2) I partially agree. (3) I am in between. } \\
\text { (4) I partially disagree. (5) I completely disagree. }\end{array}$ \\
\hline & & $\begin{array}{l}\text { When there is a discrepancy in the points of view between the govern- } \\
\text { ment and the netizens on policy-making, which one you would support } \\
\text { if you could have a choice? }\end{array}$ \\
\hline & & (1) I support the government. (2) I support the netizens. \\
\hline \multirow{2}{*}{\multicolumn{2}{|c|}{$\begin{array}{l}\text { confidence in the economic } \\
\text { development }\end{array}$}} & $\begin{array}{l}\text { Please indicate whether you agree to the statement that your country } \\
\text { can keep sustainable economic prosperity in the future. }\end{array}$ \\
\hline & & $\begin{array}{l}\text { (1) I strongly agree. (2) I agree. } \\
\text { (3) I disagree. (4) I strongly disagree. }\end{array}$ \\
\hline \multirow{2}{*}{\multicolumn{2}{|c|}{ social trust }} & $\begin{array}{l}\text { Please indicate how much confidence you have in the government, } \\
\text { stranger, media, and non-profit organizations? }\end{array}$ \\
\hline & & $\begin{array}{l}\text { (1) Much confidence (2) Some confidence, } \\
\text { (3) Little confidence (4) None at all }\end{array}$ \\
\hline \multirow{2}{*}{\multicolumn{2}{|c|}{ social responsibility }} & $\begin{array}{l}\text { Do you agree that individual interests should be protected? Do you think } \\
\text { that it could be sacrificed for the sake of national interest? }\end{array}$ \\
\hline & & $\begin{array}{l}\text { (1) Individual interests should always be protected. } \\
\text { (2) Individual interests should be sacrificed for the sake of the country. }\end{array}$ \\
\hline
\end{tabular}

Japan was struck by the huge earthquake, citizens in China and South Korea launched projects to help the Japanese victims. 9.0\% of the respondents from Beijing and 11.3\% from Seoul demonstrate their contribution. $58.1 \%$ of respondents from Beijing and $62.5 \%$ from Seoul show willingness to take part in such projects, while $33 \%$ of the interviewees from Beijing and $26.2 \%$ did not have the intention to get involved.

Table 3 reports the demographic information for speech participation. The total number of Beijing citizens 
Table 2 Citizen participation (Unit: \%)

\begin{tabular}{lccc}
\hline & Beijing & Seoul & Tokyo \\
\hline speech participation & 25.5 & 53.1 & 4.5 \\
organization participation & 16.2 & 25.8 & 13.8 \\
$\begin{array}{l}\text { political participation } \\
\text { (participation in citizen project) }\end{array}$ & 9.0 & 11.3 & - \\
\hline
\end{tabular}

who took part in online discussion on political and social issues is less than half of Seoul. Among all the respondents with positive answers from Beijing, males account for $14.9 \%$ and females account for $10.6 \%$. In terms of educational level, citizens with a graduate certificate have the highest involvement rate of $9.0 \%$ among all educational backgrounds. Students accounting for $4.5 \%$ of the total rank the first in speech participation among all professions. This is followed by laid-off workers with a proportion of $2.7 \%$. Citizens from Beijing, who are self-evaluated as the lower class, show a highest involvement rate of $12.9 \%$ among all social classes. Among all the Seoul citizens participating in online discussion, males and females account for $27.9 \%$ and $25.2 \%$, respectively. In terms of educational level, graduates have the highest involvement rate of $28.3 \%$ of all the responding Seoul citizens. Office clerks (including general employees and civil servants) show the highest involvement rate of $20.7 \%$ among all professions. In the case of Seoul, citizens who are self-evaluated as the middle class, have the highest involvement rate of $31.6 \%$ among all social classes. Tokyo citizens have the lowest involvement rate in online discussion, with males accounting for $2.6 \%$ and females accounting for 1.7\%. In terms of educational level, graduates have the highest involvement rate of $2.4 \%$. Engineers and catering and hotel staff share the highest involvement rate of $1.8 \%$, respectively among all the professions. Citizens who are self-evaluated as the middle class show the highest involvement rate of $3.2 \%$ among all social classes. In June 2012, Beijing citizens with a monthly income of 1001-2000 RMB show the highest involvement rate in online discussion (3.6\%) among all citizens with different financial backgrounds, while Seoul citizens with a total monthly income of 3.01-5 million won have the highest involvement rate $(8.4 \%)$ and Tokyo citizens with a total yearly income of 8 million JPY have the highest involvement rate (5.0\%).

Table 3 Citizen participation (Unit: \%)

\begin{tabular}{|c|c|c|c|}
\hline & Beijing & Seoul & Tokyo \\
\hline \multirow{2}{*}{ gender } & male (14.9) & male (27.9) & male $(2.6)$ \\
\hline & female(10.6) & female $(25.2)$ & female(1.7) \\
\hline education & graduate(9.0) & graduate(28.3) & graduate(2.4) \\
\hline occupation & student (4.5) & $\begin{array}{l}\text { office clerks (including } \\
\text { general employees and } \\
\text { civil servants) }(20.7)\end{array}$ & $\begin{array}{l}\text { engineers (1.8) catering } \\
\text { and hotel staffs (1.8) }\end{array}$ \\
\hline class & lower $\operatorname{class}(12.9)$ & middle class(31.6) & middle class $(3.2)$ \\
\hline income & $\begin{array}{l}\text { 1001-2000 RMB } \\
\text { monthly(3.6) }\end{array}$ & $\begin{array}{l}3.01-5 \text { million won } \\
\text { monthly }(8.4)\end{array}$ & $\begin{array}{l}8 \text { million JPY } \\
\text { yearly }(5.0)\end{array}$ \\
\hline
\end{tabular}


Table 4 Organization participation(Unit: \%)

\begin{tabular}{|c|c|c|c|}
\hline & Beijing & Seoul & Tokyo \\
\hline \multirow{3}{*}{$\begin{array}{l}\text { gender } \\
\text { education }\end{array}$} & male $(8.1)$ & male (14.5) & male (6.0) \\
\hline & female(8.1) & female(11.3) & female(7.7) \\
\hline & graduate(7.7) & graduate(16.8) & graduate(7.1) \\
\hline occupation & student (4.7) & $\begin{array}{l}\text { self-employed citizens }(5.9) \\
\text { manufacturing workers }(5.9)\end{array}$ & $\begin{array}{l}\text { office employees } \\
\text { (section chief) }(2.0)\end{array}$ \\
\hline class & lower class $(8.6)$ & middle class $(15.0)$ & middle class(10.3) \\
\hline income & $\begin{array}{l}\text { 1001-2000 RMB } \\
\text { monthly }(21.7)\end{array}$ & $\begin{array}{l}\text { 3.01-5 million won } \\
\text { monthly }(32.6)\end{array}$ & $\begin{array}{l}8 \text { million JPY } \\
\text { yearly }(34.7)\end{array}$ \\
\hline
\end{tabular}

Table 5 Citizen campaign (Unit: \%)

\begin{tabular}{lll}
\hline & Beijing & Seoul \\
\hline \multirow{2}{*}{ gender } & male $(5.2)$ & male $(6.6)$ \\
& female(3.5) & female(4.7) \\
education & senior high school or & graduate(6.3) \\
& vocational college degree (2.9) & self-employed citizens(3.3) \\
occupation & student (1.6) & serving staff $(3.3)$ \\
class & middle class(4.5) & middle class(7.0) \\
income & 2001-3000 $\operatorname{RMB}(33.3)$ monthly & $3.01-5$ million won(37.9) monthly \\
\hline
\end{tabular}

In conclusion, there are generally more males than females getting involved in online speech participation among these three cities. In terms of educational level, graduates have the highest involvement rate. In Seoul and Tokyo, citizens from the middle class hold the highest participation rate while in Beijing, the lower class people are mostly involved. Citizens who are active in citizen participation earn middle and lower level income in their respective countries.

As shown in Table 4, Beijing citizens who get involved in non-governmental organizations add up to $16.2 \%$ of all the respondents, with males and females making up $8.1 \%$, respectively. In terms of educational level, graduates have the highest participation rate of $7.7 \%$ among the various educational backgrounds, and students show the highest involvement rate of $4.7 \%$ among all professions. Citizens who are self-evaluated as the lower class have the highest involvement rate of $8.6 \%$ among all social classes. Among the Seoul citizens involved in non-governmental organizations, males take up $14.5 \%$ of the total number and females $11.3 \%$. In terms of educational level, graduates have the highest involvement rate of $16.8 \%$ among all educational backgrounds. Self-employed citizens (from a company or institution with less than nine employees) and manufacturing workers (including production leaders and factory workers) have the highest involvement rate of $5.9 \%$ respectively. Citizens who are self-evaluated as the middle class occupy 15

Table 5 reports the situation of citizen project participation in Beijing and Seoul. In the case of Beijing, 
Table 6 Engagement in policy formulation (Unit: \%)

\begin{tabular}{llll}
\hline & Beijing & Seoul & Tokyo \\
\hline pro government view & 15.8 & 20.7 & 5.8 \\
pro citizens advice & 71.2 & 57 & 54.4 \\
\hline
\end{tabular}

Table 7 Support the government's view or the netizens' advice in policy-making (Unit: \%)

\begin{tabular}{llll}
\hline & Beijing & Seoul & Tokyo \\
\hline support the government's view & 51.7 & 27.5 & 15.0 \\
support the netizens' advice & 48.3 & 72.5 & 85.0 \\
\hline
\end{tabular}

male citizens and females account for $5.2 \%$ and $3.8 \%$, respectively, among all citizens getting involved in the project. The highest involvement rate $(2.9 \%)$ is shown by citizens with an educational background of senior high school or vocational school (including both dropouts and graduates), Students occupy $1.6 \%$ of the total number and rank the first among all professions. Citizens who evaluate themselves as the middle class have the highest participation rate of $4.5 \%$ among all social classes. In the case of Seoul, $6.6 \%$ of the participants are males and $4.7 \%$ are females. Citizens with a graduate degree have the highest participation rate of $6.3 \%$ among all. Self-employed citizens (from a company or institution with less than nine employees) and serving staffs (like employees at restaurants or laundries) hold the highest participation rate of $3.3 \%$, respectively, among all professions. Citizens who are self-evaluated as the middle class have the highest participation rate of 7\%. In June 2012, Beijing citizens with a monthly income of 2001-3000 RMB have the highest involvement rate of $3.3 \%$ among citizens with different financial backgrounds. Seoul citizens with a monthly income of 3.01-5 million won have the highest involvement rate of 37.9\%. Among all the participants in these two cities, more males are getting involved in the project than females and the middle class is more active in participation than the upper and lower classes. In addition, citizens with the highest involvement rate have a middle or low level of income in their respective countries.

According to the statistic result, $15.8 \%$ of Beijing citizens, $20.7 \%$ from Seoul and $5.8 \%$ from Tokyo are in favour of the government's points of view in policies regarding effective urban development, and $71.2 \%$ of the respondents from Beijing, $57.0 \%$ from Seoul and 54.4\% from Tokyo support the idea of enhancing citizens' participation in policy-making. As showed in Table 6, Beijing ranks the first, Seoul the second and Japan the last regarding this issue.

Compared with Seoul and Tokyo, Beijing citizens show stronger desire to support the idea of citizens' participation in policy-making (Table 6). But when the government's sight is not aligned with the netizens' points of view during the policy-making process, much more citizens tend to show their support to the government than Seoul and Tokyo (Table 7), which makes the conclusion somewhat different from the result based on Table 6. $51.7 \%$ of the respondents from Beijing, $27.5 \%$ from Seoul and $15.0 \%$ from Tokyo show their support to the government when political views differ from party to party. The proportions of respondents who support the netizens' points of view reach $48.3 \%$ in Beijing, $72.5 \%$ in Seoul and $85 \%$ in 
Tokyo, respectively. In short, when there is a discrepancy in the points of view between the government and netizens regarding policy-making, Beijing has the largest group of citizens taking the side of the government, followed by Seoul and Tokyo (Table 7).

In order to gauge the respondents' confidence in economic development, they were required to rate the potentiality of sustainable economic prosperity in their home countries. The result is shown as in Table 8. Citizens who indicate answers of "strong agreement" and "agreement" are confident that the economy in their home country will continue to thrive. Beijing ranks the top among the three, with $84.45 \%$ of the respondents give positive answers. Seoul ranks the second, with $80.23 \%$ of the respondents agree. Tokyo lies at the bottom, with $56.06 \%$ of the respondents show confidence in its future economy boom. Beijing and Seoul citizens have more confidence in the future economic development in their home countries than Tokyo.

With regard to social trust, respondents were required to answer how much confidence they have in the government, stranger, media, and non-profit organizations. The result is shown as in Table 9. Among the three cities, Beijing citizens show the strongest trust in their government, with $20 \%$ having much confidence in the government and $45.4 \%$ having some. Seoul ranks the second, with $1.4 \%$ of its citizens having much confidence in their government and $28.5 \%$ having some. Tokyo ranks at the bottom, with $2.9 \%$ of its citizens having much confidence in their government and $21.1 \%$ having some. In terms of the degree that citizens trust strangers, Beijing ranks the top, with $8.4 \%$ of its citizens basically trusting strangers, followed by Tokyo $8.2 \%$ and Seoul $7.4 \%$. Regarding trust of social media, Beijing is also in the first place, with $43.2 \%$ of its citizens basically trusting the media. Seoul ranks the second (33.6\%) and Tokyo lies at the bottom (19.5\%). In terms of the degree that citizens trust non-profit organizations, Beijing ranks the first with $71.8 \%$ of its citizens basically trusting non-profit organizations. Seoul ranks in the middle (62.5\%) and Tokyo lies in the last place (42.7\%). In sum, the citizens of Beijing showed the highest confidence in the government, stranger, media, and NPOs, followed by the citizens of Seoul. The citizens of Tokyo showed least trust

Table 8 Assessment of the country's economic development (Unit: \%)

\begin{tabular}{llll}
\hline & Beijing & Seoul & Tokyo \\
\hline strong agreement & 37.88 & 19.62 & 8.25 \\
agreement & 46.57 & 60.61 & 47.81 \\
opposition & 12.42 & 17.61 & 36.73 \\
strong opposition & 3.13 & 2.15 & 7.22 \\
\hline
\end{tabular}

Table 9 Social trust (Unit: \%)

\begin{tabular}{lcccccccccccc}
\hline & \multicolumn{4}{c}{ Beijing } & \multicolumn{4}{c}{ Seoul } & \multicolumn{4}{c}{ Tokyo } \\
\hline & $\mathrm{G}$ & $\mathrm{S}$ & $\mathrm{M}$ & $\mathrm{N}$ & $\mathrm{G}$ & $\mathrm{S}$ & $\mathrm{M}$ & $\mathrm{N}$ & $\mathrm{G}$ & $\mathrm{S}$ & $\mathrm{M}$ & $\mathrm{N}$ \\
much confidence & 20 & 0.9 & 5.5 & 10.2 & 1.4 & 0.4 & 1.2 & 5.7 & 2.9 & 0.8 & 2.9 & 2.7 \\
some confidence & 45.4 & 7.5 & 37.7 & 61.6 & 28.5 & 7.0 & 32.4 & 56.8 & 21.1 & 7.4 & 16.6 & 40.0 \\
a little confidence & 25.9 & 47.5 & 43.3 & 23.2 & 49.2 & 43.4 & 54.7 & 30.7 & 51.6 & 40.5 & 55.2 & 47.5 \\
none at all & 8.8 & 44.1 & 13.4 & 5.0 & 20.9 & 49.2 & 11.7 & 6.8 & 24.4 & 51.3 & 25.3 & 9.8 \\
\hline * G: Governmt; S:
\end{tabular}

* G: Government; S: Stranger; M: Media; N: NPO 
towards government and society.

In order to measure social responsibility, participants of the survey were required to answer whether they would like to sacrifice individual interests for the sake of national interest. Table 10 reports the result. $27.7 \%$ of respondents from Tokyo insist that individual interest should be protected. This figure is the highest among these three cities and it is followed by Seoul (20.2\%) and Beijing (19.3\%). 45.5\% of respondents from Beijing, 32.4\% from Seoul and 15.2\% from Tokyo agree that individual benefits should be sacrificed for the good of the nation. To sum up, citizens in Beijing showed the highest level of collectivism, while citizens of Tokyo showed the highest level of individualism. In other words, citizens in Beijing have the strongest sense of social responsibility among citizens in these three cities.

\section{Factors Affecting Citizen Participation in Beijing, Seoul and Tokyo}

To illuminate the influential factors that promote citizen participation, correlation analysis is conducted for citizen participation, economic development, social trust, social responsibility, and demographics. As shown in Table 11, profession and speech participation are significantly related in Beijing, Seoul and Tokyo. Educational level and speech participation are correlated in Beijing. There are more well-educated Beijing

Table 10 Social responsibility (Unit: \%)

\begin{tabular}{lccc}
\hline & Beijing & Seoul & Tokyo \\
\hline $\begin{array}{l}\text { It is more important to protect the } \\
\text { individual interest. }\end{array}$ & 19.3 & 20.2 & 27.2 \\
$\begin{array}{l}\text { It is more important to consider } \\
\text { the development of the state and } \\
\text { society. }\end{array}$ & 45.5 & 32.4 & 15.2 \\
\hline
\end{tabular}

Table 11 Correlation analyses for citizen participation

\begin{tabular}{lccc}
\hline & Beijing & Seoul & Tokyo \\
\hline gender & $.094(.027)$ & $.067(.128)$ & $.058(.178)$ \\
education & $.246(.000) *$ & $.124(.165)$ & $.088(.247)$ \\
earital status & $.161(.013)$ & $.087(.698)$ & $.177(.012)$ \\
class & $.076(.199)$ & $.060(.393)$ & $.134(.009)$ \\
household income & $.137(.106)$ & $.139(.132)$ & $.111(.403)$ \\
occupation & $.378(.015) *$ & $.243(.034) *$ & $.424(.047) *$ \\
confidence of economic development & $0.58(.599)$ & $.034(.899)$ & $.059(.643)$ \\
social trust 1(government trust) & $.117(.055)$ & $.051(.717)$ & $.124(.059)$ \\
social trust 2(stranger trust) & $.153(.005)$ & $.111(.099)$ & $.184(.001)$ \\
social trust 3(media trust) & $.122(.040)$ & $.093(.215)$ & $.057(.668)$ \\
social trust 4(NPO trust) & $.117(.056)$ & $.179(.001)$ & $.136(.032)$ \\
social responsibility & $.081(.457)$ & $.132(.064)$ & $.118(.113)$ \\
\hline
\end{tabular}


Table 12 Correlation analysis between organization participation and confidence in economic development, social trust, social responsibility

\begin{tabular}{llll}
\hline & Beijing & Seoul & Tokyo \\
\hline gender & $-.005(.911)$ & $.078(.076)$ & $.027(.538)$ \\
education & $.285(.000)^{*}$ & $.177(.007)$ & $.102(.138)$ \\
marital status & $.128(.103)$ & $.115(.348)$ & $.149(.071)$ \\
class & $.115(.025)$ & $.062(.374)$ & $.051(.506)$ \\
household income & $.152(.046)$ & $.178(.013)$ & $.151(.075)$ \\
profession & $.379(.017)^{*}$ & $.123(.866)$ & $.369(.373)$ \\
confidence of economic development & $.053(.662)$ & $.098(.175)$ & $.094(.237)$ \\
social trust 1(government trust) & $.099(.145)$ & $.200(.000)^{*}$ & $.094(.233)$ \\
social trust 2(stranger trust) & $.181(.000)$ & $.088(.264)$ & $.113(.102)$ \\
social trust 3(media trust) & $.043(.789)$ & $.153(.007)$ & $.140(.023)$ \\
social trust 4(NPO trust) & $.094(.183)$ & $.121(.058)$ & $.070(.501)$ \\
social responsibility & $.162(.005)$ & $.124(.096)$ & $.153(.014)$ \\
\hline
\end{tabular}

citizens getting involved in online discussion, which shows a relatively strong correlation between these two variables. The trust in strangers is also a factor influencing citizen participation in Beijing and the speech participation in Tokyo.

In Table 12, education and profession prove to hold a strong correlation with non-governmental organization participation in the case of Beijing. The well-educated Beijing citizens show higher participation rates in non-governmental activities. In Seoul, there is a significant correlation between citizens' trust in government and the participation proportion of non-government organization activities. Household income is a factor influencing this factor for both Beijing and Seoul and social responsibility proves to be significant in the case of Beijing and Tokyo.

As indicated in Table 13, similarities are shown between Beijing and Seoul in the correlation analysis between citizen project participation and the related factors. There is a significant correlation between citizens' professions as well as their trust in government and their participation in the projects to help Japanese victims in the earthquake. The correlation between citizens' trust in strangers and their participation in this citizen project is also noticeable. Confidence in the potential economic development in China proves to be the influencing factor for Beijing.

\section{Conclusions}

This paper analyses the connection between citizen participation and the cultural, political, economic and cultural backgrounds among three big cities in East Asia area. Similarities and differences in speech participation, organization participation and political participation are discovered.

In terms of speech participation, the percentage of Seoul citizens involved in the social public life through 
Table 13 Correlation analysis between citizen project participation and confidence in economic development, social trust, social responsibility

\begin{tabular}{lcc}
\hline & Beijing & Seoul \\
\hline gender & $.097(.074)$ & $.066(.327)$ \\
education & $.192(.060)$ & $.127(.598)$ \\
marital status & $.187(.035)$ & $.196(.074)$ \\
class & $.077(.507)$ & $.044(.913)$ \\
household income & $.147(.438)$ & $.160(.364)$ \\
occupation & $.451(.351)$ & $.242(.008)^{*}$ \\
confidence of economic development & $.177(.008)$ & $.139(.130)$ \\
social trust 1(government trust) & $.190(.003)$ & $.223(.000)^{*}$ \\
social trust 2(stranger trust) & $.210(.000)^{*}$ & $.167(.027)$ \\
social trust 3(media trust) & $.197(.001)$ & $.097(.569)$ \\
social trust4(NPO trust) & $.141(.086)$ & $.102(.508)$ \\
social responsibility & $.135(.260)$ & $.113(.590)$ \\
\hline
\end{tabular}

the Internet is the highest. It is followed by Beijing and the percentage of Tokyo is the lowest. Concerning people's organization participation, the percentage of Seoul citizens participating in social activities such as NGOs is the highest, and is followed by Beijing and Tokyo.

Compared with the western society, citizens of China, Japan and South Korea tend to have a strong tendency of collectivism under the historical influence of Confucian culture. However, since this statement is based on the citizens' choice between sacrificing individual benefits and taking priority of group interests, and no attention is paid to citizens' obligations and rights, their willingness and voluntariness to participate organizational activities, it is difficult to reach a conclusion that collectivism is the leading spirit in public social life in these three countries.

In projects launched by volunteer citizens to help Japanese victims in the earthquake, Beijing citizens lag far behind their Seoul counterparts in terms of contribution and participation awareness . Beijing, Seoul and Tokyo citizens all support the idea that citizens' voice should be reflected in policy-making. Compared with citizens of Seoul and Tokyo, Beijing citizens have a stronger request in this aspect. But in the case that citizens have a dispute with the government in policy-making, Beijing citizens show the highest percentage in supporting their government. The proportion of Beijing citizens supporting the netizens in policy-making ranks at the bottom, while the percentage of Tokyo citizens lies on the top. Hence, it can be possibly concluded that Beijing citizens trust their government in its decision-making ability more than the netizens.

In short, judging from this comparative study about the citizen participation situation in Beijing, Seoul and Tokyo, Seoul citizens show the highest enthusiasm and voluntariness in participating in public online discussion, with Beijing citizens ranking in the middle and Tokyo citizens at the bottom. A large proportion of the citizens from these three cities have never participated in any social activities like NGOs. Seoul citizens show the highest percentage with positive answer regarding this issue. Beijing ranks the second and Tokyo 
is in the last place. Beijing citizens lag behind Seoul citizens in respect of citizen project participation.

The difference in speech, organization and political participation among Beijing, Seoul and Tokyo citizens is directly connected with the economic, political, cultural and social backgrounds in these three countries. What are the main factors affecting citizen participation? According to analysis result of this investigation, profession, social trust, household income, social responsibility and confidence in sustainable economic development are the influencing factors. Profession is the factor closely related to speech participation of citizens from all three cities; Education level is a main factor influencing Beijing citizens' speech participation; the trust in strangers affects citizens' speech participation in both Beijing and Tokyo. Education and profession are closely related to Beijing citizens' organization involvement; the trust in the government is closely related to Seoul citizens' organizational involvement. Household income affects citizens' involvement in non-governmental organizations in Beijing and Seoul; social responsibility affects this factor in the case of Beijing and Tokyo. Trust in strangers is closely related to Beijing citizens' involvement in the citizen project to help Japanese victims in the disaster; their trust in the government, marital status, trust in the media and confidence in future economic development in China also affect their willingness to participate in this project to a certain degree. Profession, trust in government and trust in strangers are the factors closely related to Seoul citizens' participation rate in this citizen project.

Furthermore, the above conclusions can be perceived from the macro perspectives of participation environment administration and social structure:

(1) Social Participation Environment Administration

Frequent use of the Internet is directly related to the increase of voluntary organization participation and political participation. With the spreading of the Internet, there has been a rapid increase in the number of netizens in China (CNNIC, 2014). Frequent information exchange has largely promoted citizens' awareness to participate in social events and activities. Social participation is considered part of the duty and responsibility of citizens, and more and more netizens from all social classes are willing to get involved in public service and voluntary activities, such as environment protection project, community service, sports activity and charity donation. In addition, in case of influential social events, Chinese citizens tend to express their opinions through multiple channels and are more enthusiastic in participating in the national decisionmaking process. Citizens' awareness and voluntariness in participating social activities are greatly improved by the Internet. Therefore, the percentage of Beijing citizens engaged in online speech participation is the highest among these three cities.

According to 2012 E-government Investigation Report by UN, the average global e-government development index is 0.4882 , with East Asia scoring 0.6344 leading the world. With a total score of 0.9283 , South Korea continues to rank No.1 in global e-government development, while China ranks the 78th with a total score of 0.5359. This figure dropped 6 places compared with 2010, but at the same time, China has made progress in promoting online transparency and openness (UN, 2012). Among the top-level countries in respect to "social participation environment administration", South Korea ranks the first, Japan the 10th. While in term of "online communication between citizens and government", Japan ranks the lowest among the eighteen interviewed countries, including Sweden, Finland, Denmark, Holland and Norway (Central 
Research Services, 2010).

From the above statistics, we can see that South Korea has done the best in social participation environment administration in the world, outperforming both China and Japan. Therefore, it is not surprising that the percentage of Seoul citizens participating in social public life is the highest among these three cities. As mentioned above, since the percentage of Japanese citizens communicating with the government online is the lowest among the eighteen countries investigated, the percentage of Japanese citizens involved in online speech participation is the lowest among Beijing, Seoul and Tokyo.

(2) Social Structure

In China, from 1950s to the late 1970s, urban labors were mostly affiliated with state-owned organizations and institutions. Their acquisition of information on social life and social resources heavily depended on their affiliations and and the information they received this way affected their private life as well (Bian, 1996). Therefore, in China, the concepts of "state" and "society" have always been highly overlapped, and almost all NGOs are dominated by the government. This social structure has led Chinese citizens to a dependent and passive thinking pattern, which embodies the idea that "I am obliged to do what the state asks me to". Citizens are motivated to take part in some activities organized by the government and their personal willingness was ignored. Under the prehistoric influence of the Internet, the online-based nongovernmental organizations sprung up and the various social forces developed. People with mutual interests gather together and promote their activities in various forms. However, within the influence of institutional and social framework in the old days, citizens getting involved in citizen participation only account for 16.2

"Vertical society" (Nakane, 1967) is the term often used to describe the social structure in Japan. It refers to individual loyalty to an association or a group through the serialization of interpersonal relationships (Hama, 1997). A marked feature of the Japanese society is group-orientation, with almost every individual affiliated to a certain group. In Japan, it is difficult to accomplish your personal ambitions without support of other people. People are getting involved in groups for the benefit of potential favor. Japanese companies have established systems for life-long employment, welfare insurance and seniority-based wage in order to enhance the sense of belonging of its employees. Group-orientation is interwoven with differentiated attitudes towards insiders and the outsiders, which range from family, community, workplace and the whole country. Japanese employees passionately devote themselves to the group they belong to, isolating themselves from the outside world. They prefer to communicate with people, with whom they have already established a reliable relationship. This social structure and interpersonal relationship directly influence the result of speech participation, organization participation and political participation of Japanese citizens in this survey

In conclusion, this research centers around the effect of educational level, economic status, social status, traditional culture and social structure on citizen participation through an investigation with citizens in Beijing, Seoul and Tokyo. It argues that educational level, economic status and social status are the factors that influence citizen participation. In addition, profession, social trust, social responsibility and confidence of the citizens in potential economic development of their home countries are also responsible. Furthermore, this study explores the citizen participation issue from macro perspectives of participation environment 
administration and social structure, which further deepen and complement other research findings.

\section{References}

Bian, Y.J. etc.,1996. "Danweizhi Yu Zhufang Shangpinhua (Commercialization of Housing in China)." Sociological Studies, Issue 1, pp.83-95. Beijing, China.

Catherine Newcomb's. etc., 2003. Meet the Challenges of Performance-oriented Government, Translated by Zhang Meng-zhong.etc. Guangzhou, China: Zhongshan University Press.

Central Research Services, (2010). Investigation on the Internet. Retrieved on June 30, 2012 from http: //www.crs.or.jp/data/pdf/internet10.pdf

Duan, S.J. and Zhang, H., 2008. "Laonianren Shehui Canyu de Gainian he Lilun Jichu Yanjiu (Theoretical Research of Social Participation among Senior Citizens)." Journal of Adult Education College of Hebei University, Issue 3, pp.82-84. Shijiazhuang, China.

Feng, C.B., 2008. "Minjian Zuzhi zai Cujin Gongmin Canyu zhong de Zuoyong Fenxi (Role of Nongovernmental Organizations in Promoting Citizen Participation)." Theoretical Exploration, Issue 6, pp.128-130. Taiyuan, China.

Fu, J.J., 2009. "Wangluo Canyu de Bijiaoxing Fenxi (Comparative Analysis of Network Participation)." Across the Academic Field • 栗 ssue 6, pp.121. Lanzhou, China.

Gordon, P. Whitaker., 1980. "Coproduction: Citizen Participation in Service Delivery", Public Administration Review, Vol. 40, Issue 3, pp.240-246. New Orleans, USA.

Hama, R., Takeuchi, I. and Ishikawa, A., 1997. Small Dictionary of Sociology. Tokyo, Japan: Yuhikaku Publishing.

Li, Y. S. and Liu, C. X., 1995. "Zhengzhi Canyu: Hanyi, Tezheng he Gongneng (Political Participation: Connotations, Features and Functions)." Academic Exchanges, Issue 6, pp. 64-69. Harbin, China.

Liu, M.H., 2005. "Lun Gonggong Zhengce Canyu de Yingxiang Yinsu (Influencing Factors of Citizen Participation)." Journal of Xiangtan University - Philosophy and Social Sciences, Issue 5, pp. 93-95. Xiangtan, China.

Liu, F., 2011. "Wangluo Shidai de Qingnian Shehui Canyu he Gonggong Jingshen Peiyu (The Social Participation of younger generation and the Training of Social Spirit)." Journal of Beijing Youth Politics College, Issue 4, pp.20-24. Beijing, China.

Min, X.Q., 2010. "A Comparative Research on Citizen Participation Status of the Youth in China, Japan and Korea", Youth Studies, Issue 6, pp. 63-71. Beijing, China.

Nakane, C., 1967. Interpersonal Relation in Vertical Society • 卦 ranslated by Chen Cheng, 1994. Beijing, China: Commercial Press.

Robert, A. Dahl., 1994. "A Democratic Dilemma: System Effectiveness Versus Citizen Participation” • 訓 olitical Science Quarterly, Vol.109, Issue 1, pp.23-34. New York, USA.

Shu, S. M., 2005. "On the Theory of Political Participation in West", Journal of China National School of Administration, Issue 5, pp.89-91. Beijing, China. 
Sun, B.Y., 2005. "An Analysis of the Types and Effectiveness of Citizen Participation Forms", Journal of Renmin University of China, Issue 5, pp.124-129. Beijing, China.

Tang, Y. L., 2009. "Wangluo Zhengzhi Kongjian yu Gongmin Zhengzhi Canyu (Network Political Space and Citizen Political Participation).", Wenhui, March 17, 2009. Shanghai, China.

Tsutsui, K. and Christine, M. W. 2004. "Global Civil Society and the International Human Rights Movement: Citizen Participation in Human Rights International Nongovernmental Organizations", Social Forces, Vol. 83, Issue2, pp.587-620. Beijing, China.

Thomas, W. and Seth, T., 2000. "Fairness and Competence in Citizen Participation: Theoretical Reflections from a Case Study" • 窟 dministration \& Society. Vol. 32, Issue 3, pp. 567-572. New York, USA.

United Nations (UN), 2012. “2012 Nian Lianheguo Dianzi Zhengwu Diaocha Baogao•哺 ianxiang Gongzhong de Dianzi Zhengwu ("2012 E-government Investigation Report: E-government serving the public)". Electronic Government, Issue 4, pp. 95. Beijing, China.

Wang, L.F. and Ni, X., 2005. "Woguo Jingji Shehui Zhuanxingqi de Zhengfu Guanli Chuangxin Yanjiu (Research on the Innovation of Government Management in China), Academic Research, Issue 4, pp. 75-78. Guangzhou, China.

Wang, W.Q., 2008. "Citizen Participation: Experience on the Administrative Accountability in China." Proceedings of 2009 International Conference on Public Administration (4th), Vol. I, pp. 327-333. Chengdu, China.

Wang, X.A., 2013. "Gonggong Zhengce Guocheng zhong de Gongmin Canyu: Jiazhi Yingxiang Yinsu yu Zhanlue Mubiao (Policies on Citizen Participation in Public Policies: Values, Influencing Factors and Strategic Objectives)." Journal of Changchun Communist Party Institute, Issue 4, pp.66-70. Changchun, China.

Wei, X.H. and Ou, Y.B., 2007. "Minjian Zuzhi shi Woguo Gongmin Youxu Canyu de Zhongyao Zaiti (The Non-governmental Organization is an Important Carrier of China's Orderly Citizen Participation), Journal of Fujian Party School, Issue 4, pp.40-43. Fuzhou, China.

Wu, S.Q., Zheng, H.L., 2008. Gongmin Canyu Gonggong Zhengce Zhiding de Zhiyue Yinsu ji qi Duice Yanjiu (Restrictions of Public Policies on Citizen Participation )." Journal of Liaoning Administration College, Issue 6, pp.21-22. Shenyang, China.

Yu, K.P., 2006. "Gongmin Canyu de Jige Lilun Wenti (Several Academic Problems on Citizen Participation)." Study Times, pp.12-18. Beijing, China.

Zhang, C. and Zhou, Q.R., 2010. "Wangluo Shehui de Qunti Canyu: yi Renkou Shehuixue wei Shijiao (Social Network Participation : From the Perspective of Demographic Sociology), Scientific and Technological Information, Issue 10, pp. 460. Jinan, China.

Zhang ${ }^{1)}$, H.M., 2011. "Individual Voice and Citizen Participation on the Cyber World", Journal of North China Institute of Water Conservancy and Hydroelectricity (Social Sciences Edition), Issue 2, pp. 44-46. Zhengzhou, China.

Zhang ${ }^{2)}$, L., 2011. "Gongmin Wangluo Canyu dui Gonggong Zhengce Zhiding de Yingxiang (Influence of Citizen Network Participation on Policy-making)." Journal of Chongqing University of Science and Tech- 
nology (Social Sciences Edition), Issue 16, pp. 20-21. Chongqing, China.

Zhou, X.L., 2005. "Lun Gonggong Zhengce zhong de Gongmin Canyu (Policy on Citizen Participation in China)." Journal of the Party School of CPC Changchun Municipal Committee • 栗 ssue 6, pp. 47-51. Changchun, China.

Zhu, Y.S., 2010. "Liangxing Hudong: Qingnian Wangluo Zhengzhi Canyu de Fazhan Xin Qushi (Virtuous Interaction: the New Trend of young generation in Network Political Participation), China Youth Research, Issue 1, pp. 17-21. Beijing, China. 